\title{
LIVER CYTOCHROME P450-HYDROXYLATION SYSTEM OF TUMOR-BEARING RATS UNDER THE INFLUENCE OF $\omega$-3 POLYUNSATURATED FATTY ACIDS AND VITAMIN $D_{3}$
}

\author{
I. O. SHYMANSKYI ${ }^{1}$, O. V. KETSA ${ }^{2}$, M. M. MARCHENKO ${ }^{2}$ M. M. VELIKY ${ }^{1}$ \\ ${ }^{1}$ Palladin Institute of Biochemistry, National Academy of Sciences of Ukraine, Kyiv; \\ 凶e-mail: ihorshym@gmail.com; \\ ${ }^{2}$ Fedkovich Chernovtsy National University, Chernovtsy
}

\begin{abstract}
The study was performed to investigate the effects of the separate and combined action of omega-3 polyunsaturated fatty acids ( $\omega-3$ PUFAs) and vitamin $D_{3}$ on the activity of the components of the oxygenase and reductase chains of the monooxygenase system (MOS) in the microsomal fraction isolated from the liver of rats with transplanted Guerin carcinoma. In the liver of the tumor-bearing rats during the intensive growth of the tumor (14 days, which corresponds to the logarithmic phase of tumor growth), the functional activity of the MOS was weakened. N-demethylase, p-hydroxylase and NADPH-cytochrome P450 reductase activity decreased, with the simultaneous enhancement of cytochrome P450 inactivation rate due to its transformation into an inactive form, cytochrome P420. In turn, we found an increase in the functional activity of the reductase chain of MOS, which components are known to transfer electrons from the reduced NADH through $N A D H$-cytochrome $b_{5}$-reductase and cytochrome $b_{5}$ to cytochrome P450. In particular, the activity of NADHcytochrome $b_{5}$-reductase and the rate of reduction of cytochrome $b_{5}$ were elevated with a simultaneous decrease in its content. Both $\omega-3$ PUFAs and vitamin $D_{3}$ administration to tumor-bearing rats for 42 days (28 days of preliminary administration and 14 days of tumor growth) normalized the oxygenase activity of MOS, increasing NADPH-cytochrome P450-reductase, N-demethylase and p-hydroxylase activity of cytochrome P450 and blocking cytochrome P450 inactivation rate in the microsomal fraction of the liver. Administration of $\omega-3$ PUFAs in combination with vitamin $D_{3}$ led to the synergy. Changes in the activity of the components of the reductase chain of MOS in liver of tumor-bearing rats were observed mainly after $\omega-3$ PUFAs supplementation. The content of cytochrome $b_{5}$ increased and the rate of its reduction was significantly diminished. In the absence of a pronounced individual effect of vitamin $D_{3}$ on the reductase chain of MOS, its co-administration with $\omega-3$ PUFA was also found to be ineffective.
\end{abstract}

Keywords: $\omega-3$ polyunsaturated fatty acids, vitamin $D_{3}$, cytochrome P450, NADPH-cytochrome P450reductase, cytochrome $b_{5}$, NADH-cytochrome $b_{5}$-reductase, microsomal fraction, liver.

$\mathrm{T}$ he susceptibility of transformed malignized cells to the action of cytostatics is largely determined by the functional efficacy of the enzymatic systems of detoxification both in the tumor itself and in the surrounding tissues. The mechanism of intracellular oxidative modification of exogenous and endogenous compounds is directly related to the activity of cytochrome P450 (CYP)-containing oxygenase system (monooxygenase system - MOS) of the endoplasmic reticulum (ER), which metabolizes not only xenobiotics, but also natural substrates, including polyunsaturated fatty acids (PUFAs) and vitamin $\mathrm{D}_{3}[1,2]$.

Liver CYP-hydroxylation system is involved in the metabolism of PUFAs, which oxidation leads to the formation of hydroxylated and epoxy derivatives of fatty acids. The resulting oxygenated PUFAs derivatives can affect the proliferation of cells in different ways, since the spectrum of these metabolites depends on the structural features of the $\omega-3$ and $\omega-6$ PUFAs consumed. The hydroxyeicosatetraenoic (HETE) and epoxyeicosatrienoic (EET) acids

(C) 2018 Shymanskyi I. O. et al. This is an open-access article distributed under the terms of the Creative Commons Attribution License, which permits unrestricted use, distribution, and reproduction in any medium, provided the original author and source are credited. 
derived from arachidonic acid ( $\omega-6$ PUFA) stimulate cell proliferation and promote carcinogenesis [3], while epoxyeicosatetraenoic (EEQ) and epoxydocosapentaenoic (EDP) acids, eicosapentaenoic acid (EPA) and docosahexaenoic acid (DHA) derivatives ( $\omega-3$ PUFA), respectively, exhibit anticarcinogenic properties [4].

Since vitamin D possesses immunomodulatory, anti-inflammatory effects and can activate differentiation and inhibit cellular proliferation, its insufficiency in the body causes the development of chronic autoimmune, cardiovascular, inflammatory, allergic diseases and bone pathologies (osteoporosis, osteomalacia). Vitamin D bioavailability might be of particular importance for preventing neoplastic transformation of cells and the progression of cancer [5]. The metabolism of vitamin D in the body is provided by the functioning of a number of CYP isoforms (CYP2R1, CYP27A1, CYP27B1) [6], which ensure the formation of active metabolites (25OHD, $\left.1,25(\mathrm{OH})_{2} \mathrm{D}\right)$. Inactivation of the latter is mediated by the action of catabolic CYP - CYP24A1 [7]. The microsomal isoforms of hepatic vitamin D 25-hydroxylase (CYP2R1, CYP2J2/3) are considered to be regulatory enzymes that actively function at physiological concentrations of vitamin D and are inhibited by the reaction product - 25OHD [8].

In addition to the known molecular mechanisms of the antitumor effect of $\omega-3$ PUFAs and vitamin $\mathrm{D}_{3}$ (cholecalciferol), the influence of these lipophilic nutrients on the functional state of CYPhydroxylation system of the liver with developing malignant process remains unclear.

The purpose of the study was to elucidate the effects of separate and combined action of $\omega-3$ PUFAs and vitamin $\mathrm{D}_{3}$ on the function of liver microsomal CYP-hydroxylation system in rats with transplanted Guerin's carcinoma.

\section{Materials and Methods}

All studies were carried out on white female rats weighing 90-110 g. The animals were kept on a standard balanced diet.

As a model of malignant neoplasm, Guerin's carcinoma was used. Carcinoma transplantation was performed by subcutaneous injection of $0.5 \mathrm{ml}$ of a $30 \%$ saline suspension of cancer cells to the upper thigh of the right rat limb according to the described procedure [9]. Animal experiments were conducted in accordance with the International conventions of animal protection and the requirements of the Di- rective 86/609/EEC on animal used for experimental purposes.

The animals were divided into the following groups: I - control (intact animals) II - rats with transplanted Guerin's carcinoma; III - tumorbearing rats daily administered with $\omega-3$ PUFAs (120 mg/kg body weight, per os) in the form of the commercial drug Vitrum Cardio Omega-3 (manufactured by Unipharm, Inc., USA); IV - tumor-bearing rats daily supplemented with vitamin $\mathrm{D}_{3}$ in the form of oil suspension (600 IU/kg body weight, per os); $\mathrm{V}$ - tumor-bearing rats, which were administered with $\omega-3$ PUFAs in combination with vitamin D3 in the indicated doses.

$\omega-3$ PUFAs, in particular eicosapentaenoic acid (EPA) and docosahexaenoic acid (DHA) and vitamin $D_{3}$, were pre-administered for 28 days before the transplantation of Guerin's carcinoma and after the transplantation for the entire period of tumor growth (14 days).

Decapitation of animals was carried out under light ether anesthesia on the 14th day of carcinoma growth, which corresponds to the logarithmic phase of tumor growth.

The microsomal fraction was obtained from rat liver by differential centrifugation [10]. In the suspension of the microsomal fraction, the enzymatic activities of the components of the MOS oxygenase chain - NADPH-CYP-reductase activity, p-hydroxylase and $\mathrm{N}$-demethylase activity of CYP were studied [11]. The hydroxylase activity of CYP was determined by the rate of hydroxylation of aniline estimated by the amount of 4-aminophenol formed, which in the presence of sodium carbonate forms a blue indophenol complex with phenol. The $\mathrm{N}$-demethylase activity of CYP was detected by the amount of formaldehyde formed as the result of dimethylaniline demethylation [11]. The rate of transition of microsomal CYP to its inactive form P420 was recorded from differential absorption spectra of reduced carboxycomplexes of hemoproteins at 420 $\mathrm{nm}$ and $450 \mathrm{~nm}$ measured every $3 \mathrm{~min}$ and expressed as $\Delta \mathrm{A}_{420-450}$ per nmol of CYP [12]. The CYP content was assayed by the method described by Omura and Sato [13].

The functional state of the reductase chain of MOS was assessed by NADH-cytochrome $b_{5}$-reductase activity, by the content and rate of reduction of cytochrome $b_{5}$ in its redox transformations [11]. The recovery rate of cytochrome $b_{5}$ is recorded with a differential absorption spectrum at a wavelength of 
$424 \mathrm{~nm}$ and $475 \mathrm{~nm}$ every $30 \mathrm{sec}$ and expressed as $\Delta \mathrm{A}_{424-475}$ per mg of protein. The protein content in the samples was determined by the Lowry protein assay [14]. The results were processed by the variational statistics method using Student's $t$-test.

\section{Results and Discussion}

Our results have shown that at $14^{\text {th }}$ day of Guerin' carcinoma development the hydroxylase activity of CYP decreased in the microsomal fraction of the liver of tumor-bearing rats (Fig. 1). A comparative analysis of the hydroxylation of type I and II substrates suggested that the hydroxylation of type I substrates (dimethylaniline to formaldehyde) was reduced to a greater extent. CYP N-demethylase and p-hydroxylase activities (hydroxylation of aniline, substrate type II with the formation of 4-aminophenol) decreased 2.6- and 1.5-fold respectively (Fig. 1, $A$ and $B$ ). The difference in the rate of hydroxylation of type I and II substrates can be associated with impairments in the lipid bilayer of the liver ER during intensive tumor growth [15]. It is known that type I substrates interact with the hydrophobic region of apoenzyme CYP, which activity strongly depends on the alterations of membrane viscosity [16]. Under conditions of tumor growth, the initiation of lipid peroxidation (LPO) processes in liver ER membranes can lead to disruption of the phospholipid bilayer and, as a consequence, to changes in the structural and functional conformation of membrane-associated CYP. As one of the in- dices of conformational changes in CYP, we found an increase in the rate of the formation of its inactive form - cytochrome P420 (Fig. 2).

It is known that the microsomal isoform of liver vitamin D 25-hydroxylase catalyzes the first stages of cholecalciferol hydroxylation in the $25^{\text {th }}$ position to produce 25-hydroxyvitamin $\mathrm{D}$ - the main transport and cumulative form of vitamin D. The rate of this process in the liver largely depends on the structure of the phospholipid bilayer of ER, in which the components of the hydroxylating system are localized [8]. $\omega-3$ PUFAs stabilize the architecture of membrane lipids and, thereby, ensure the optimal structural and functional conformation of the MOS components as integral membrane-associated enzyme complexes within different regions of ER [17]. Given aforementioned and that $\omega-3$ PUFAs and vitamin $\mathrm{D}$ can participate in the regulation of the life cycle of tumor cells, reducing proliferation, metastasis formation and increasing the apoptotic death of transformed cells [18], it was advisable to test their separate and combined effects in the liver of tumorbearing rats.

Study of the effect of lipophilic nutrients on the CYP hydroxylase activity showed that the separate administration of $\omega-3$ PUFAs and vitamin $D_{3}$ substantially normalizes the hydroxylase activity of MOS. N-dimethylase (Fig. 1, A) and p-hydroxylase (Fig. 1, B) activities of CYP were found to be increased in the microsomal fraction of the liver of tumor-bearing rats. Effect of $\omega-3$ PUFAs on these
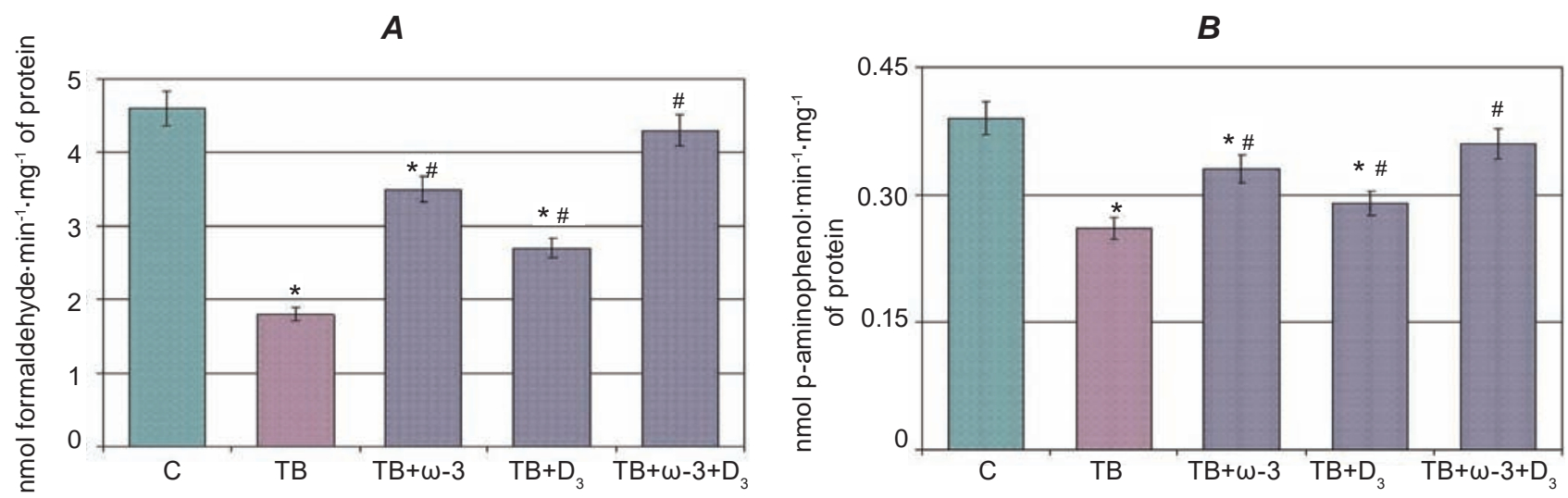

Fig. 1. The ffects of $\omega-3$ polyunsaturated fatty acids and vitamin $D_{3}$ on $\mathrm{N}$-demethylase (A) and p-hydroxylase (B) activity of CYP in the liver microsomal fraction of tumor-bearing rats: $C$-intact animals; TB - tumorbearing rats in the period of intensive growth of the Guerin's carcinoma; TB+ $\omega-3$-tumor-bearing rats that were administered with $\omega-3$ PUFAs; $T B+D_{3}$-tumor-bearing rats that were administered with vitamin $D_{3}$; $T B+\omega-3+D_{3}-$ tumor-bearing rats that were administered with $\omega-3$ PUFAs and vitamin $D_{3}$; *statistically significant difference vs. control ( $P \leq 0.05)$; " statistically significant difference vs. tumor-bearing rats $(P \leq 0.05)$ 
activities was more pronounced than that of vitamin $D_{3}$. At the same time, the rate of formation of the inactive form of cytochrome P420 was decreased (Fig. 2).

The correcting effect of $\omega-3$ PUFAs on the hydroxylase activity of CYP in the microsomal fraction of rat liver with transplanted Guerin's carcinoma can be explained by activation of the antioxidant defense system, probably, due to stabilization of ER membrane structures. On the other hand, $\omega-3$ PUFAs are known precursors of oxygenated metabolites formed in the CYP-dependent pathway, involving CYP isoforms from the family 2 (CYP2C8, CYP2E1), which may exhibit a protective effect on ER membrane structures [19, 20].

The increase in the hydroxylase activity of CYP in the liver microsomes of tumor-bearing rats administered with vitamin $\mathrm{D}_{3}$ can be attributable to the action of CYP2R1 isoform, which is an inducible enzyme and is synthesized in response to

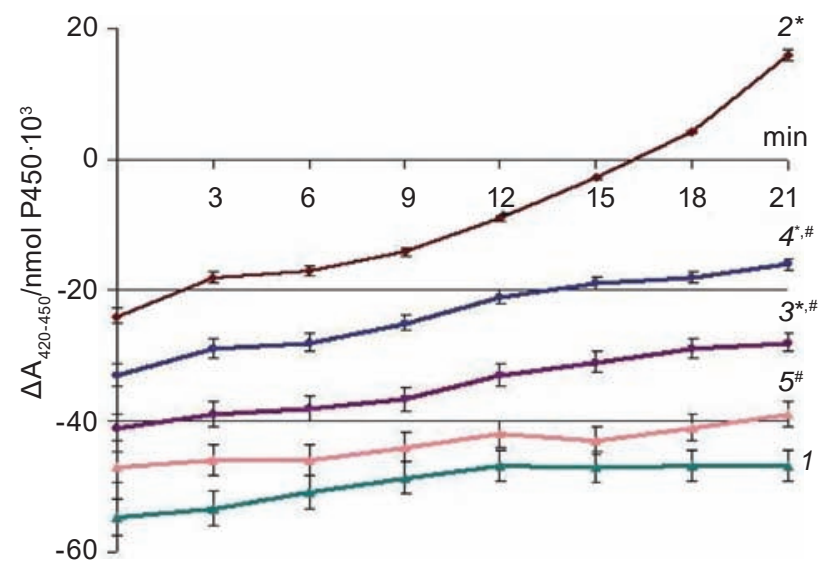

Fig. 2. The effects of $\omega-3$ polyunsaturated fatty ac$i d s$ and vitamin $D_{3}$ on the rate of CYP inactivation accompanied by the formation of P420 in the liver microsomal fraction of tumor-bearing rats: 1 - intact animals; 2 - tumor-bearing rats in the period of intensive growth of the Guerin's carcinoma; 3 tumor-bearing rats that received $\omega-3$ PUFAs before and after transplantation of Guerin's carcinoma; 4 - tumor-bearing rats that were administered with vitamin $D_{3}$ before and after transplantation of Guerin's carcinoma; 5 - tumor-bearing rats that were administered with $\omega-3$ PUFA and vitamin $D_{3}$ before and after transplantation of Guerin carcino$m a ; *$ statistically significant difference vs. control $(P \leq 0.05) ;{ }^{*}$ statistically significant difference vs. tumor-bearing rats $(P \leq 0.05)$ increased contents of the substrate - cholecalciferol. It is known that transcriptional regulation of gene expression of vitamin D hydroxylating enzymes is carried out by the hormonally active form of vita$\min \mathrm{D}-1,25(\mathrm{OH})_{2} \mathrm{D}[8]$.

Combined administration of $\omega-3$ PUFAs and vitamin $\mathrm{D}_{3}$ resulted in mutually enhancing effect as changes in the $\mathrm{N}$-demethylase and p-hydroxylase activity of CYP were more pronounced than after their separate application (Fig. 1).

The intensity of the process of hydroxylation of substrates by CYP is largely determined by the activity of NADPH-CYP-reductase and cytochrome $b_{5}$, which are redox partners in electron transferring at the second (NADPH-CYP-reductase) and the fifth (NADPH-CYP-reductase or cytochrome $b_{5}$ ) stages of the monooxygenase cycle [17]. Our data indicate a decrease in the activity of NADPH-CYP-reductase in rat liver microsomal fraction during the intensive growth of the Guerin's carcinoma (Fig. 3). This might cause a delay in the transfer of electrons from this flavoprotein to CYP and induce a decrease in the hydroxylase activity of CYP (Fig. 1).

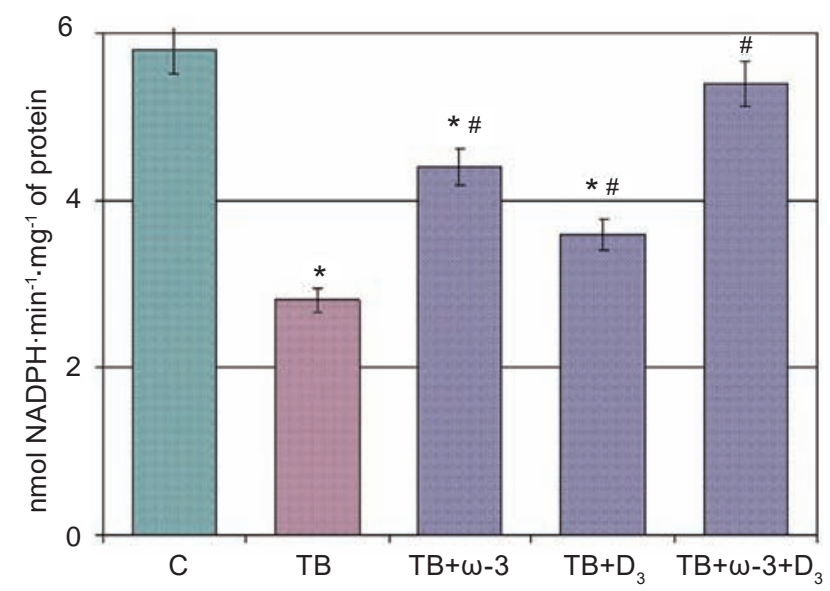

Fig. 3. The activity of NADPH-CYP-reductase in the liver microsomal fraction of tumor-bearing rats and: effects of $\omega-3$ polyunsaturated fatty acids and vitamin $D_{3}$ treatment: $C$ - intact animals; $T B-t u$ mor-bearing rats in the period of intensive growth of the Guerin's carcinoma; TB+ $\omega-3$ - tumor-bearing rats that were administered with $\omega-3$ PUFAs; $\mathrm{TB}+\mathrm{D}_{3}$-tumor-bearing rats that were administered with vitamin $D_{3} ; T B+\omega-3+D_{3}-$ tumor-bearing rats that were administered with $\omega-3$ PUFAs and vitamin $D_{3}$; * statistically significant difference vs. control $(P \leq 0.05)$; ${ }^{*}$ statistically significant difference vs. tumor-bearing rats $(P \leq 0.05)$ 


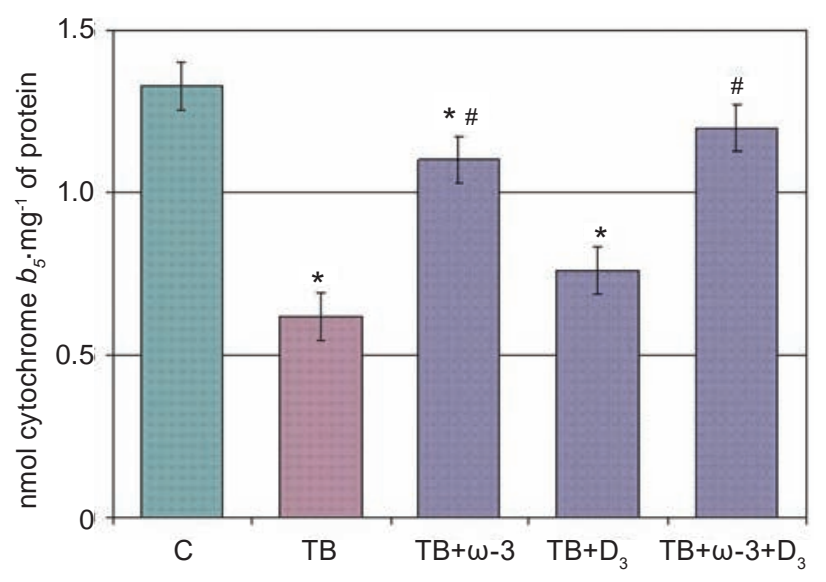

Fig. 4. Cytochrome $b_{5}$ content in the liver microsomal fraction of tumor-bearing rats: effects of $\omega-3$ polyunsaturated fatty acids and vitamin $D_{3}$ treatment: $C$ - intact animals; TB - tumor-bearing rats in the period of intensive growth of the Guerin's carcinoma; $T B+\omega-3$-tumor-bearing rats that were administered with $\omega-3$ PUFAs; $T B+D_{3}$ - tumorbearing rats that were administered with vitamin $D_{3}$;

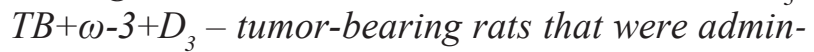
istered with $\omega-3$ PUFAs and vitamin $D_{3}$; *statistically significant difference vs. control $(P \leq 0.05)$; ${ }^{\#}$ statistically significant difference vs. tumor-bearing rats $(P \leq 0.05)$

Both separate and, especially, combined supplementation of $\omega-3$ PUFAs and vitamin $\mathrm{D}_{3}$ led to the rise of NADPH-CYP-reductase activity in the microsomal fraction of the liver. The activation mechanism can be related to the ability of PUFAs to incorporate into membrane phospholipids, which may lead to the changes in the membrane composition of $\omega-6$ PUFAs. In addition, enhanced synthesis of the hormonally active form of vitamin $\mathrm{D}_{3}$ can occur that may contribute to the activation of membrane protein-receptors. $1,25(\mathrm{OH})_{2} \mathrm{D}$ has the ability to reduce the intracellular level of calcium and the expression of the inducible form of NO synthase, accompanied by a decrease in the formation of peroxynitrite (ONOO-), monoxide and nitrogen dioxide (NO; $\mathrm{NO}_{2}{ }^{-}$) in cells. At the same time, vitamin D stimulates the expression of cellular $\gamma$-glutamyl transpeptidase and activates the glutathione-dependent antioxidant defense system [18]. Thus, the combined administration of $\omega-3$ PUFAs and vitamin $\mathrm{D}_{3}$ is accompanied by an increase in the activity of the components of the MOS oxygenase chain compared to those of tumor-bearing rats that did not receive the lipophilic nutrients.
An important role in the regulation of the CYP monooxygenase cycle is played by the components of the MOS reductase chain, which transfer electrons from the reduced NADH via NADH-cytochrome $b_{5}$ reductase and cytochrome $b_{5}$ to CYP [21].

Guerin's carcinoma growth was shown to be accompanied by a decrease in cytochrome $b_{5}$ content (Fig. 4) with simultaneous increase in NADHcytochrome $b_{5}$-reductase activity (Fig. 5) in the liver microsomal fraction. It should be noted that a decrease in the content of cytochrome $b_{5}$ can, at least partially, be compensated by an increase in the rate of its redox transformations (Fig. 6). Accordingly, the activation of electron transfer in the reductase chain of the monooxygenase system can enhance the formation of superoxide radicals as a key event in the CYP monooxygenase cycle.

While unchanging the activity of NADH-cytochrome $b_{5}$-reductase, long-term administration of $\omega-3$ PUFAs exerted a pronounced effect on other components of the MOS reductase chain (Fig. 5). In particular, the content of cytochrome $b_{5}$ (Fig. 4) increased and the rate of its reduction was significantly diminished (Fig. 6). Regulatory influence of

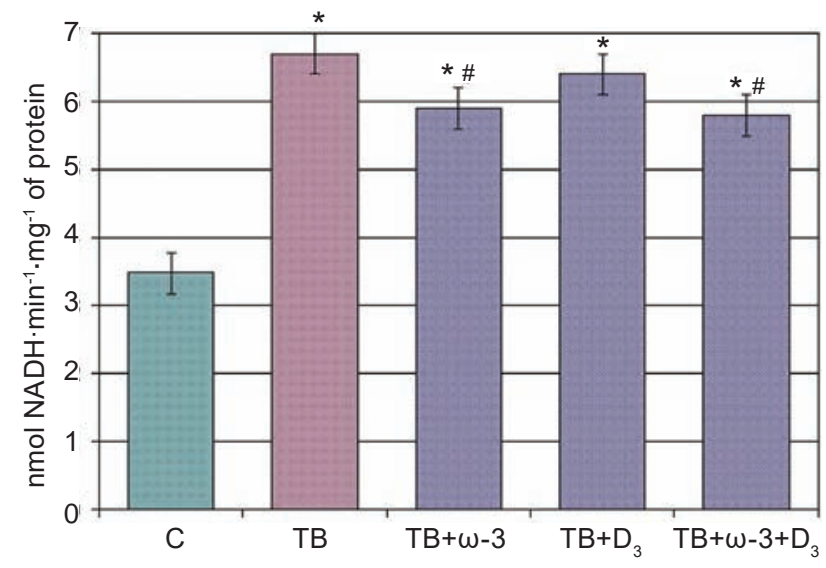

Fig. 5. The activity of NADH-cytochrome $b_{5}$-reductase in the liver microsomal fraction of tumorbearing rats: effects of $\omega-3$ polyunsaturated fatty acids and vitamin $D_{3}$ treatment: $C$ - intact animals; $T B$ - tumor-bearing rats in the period of intensive

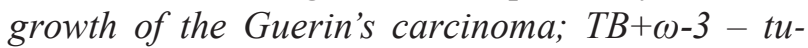
mor-bearing rats that were administered with $\omega-3$ PUFAs; $T B+D_{3}$ - tumor-bearing rats that were administered with vitamin $D_{3} ; T B+\omega-3+D_{3}-t u-$ mor-bearing rats that were administered with $\omega-3$ PUFAs and vitamin $D_{3}$; * statistically significant difference vs. control $(P \leq 0.05)$; ${ }^{*}$ statistically signifcant difference vs. tumor-bearing rats $(P \leq 0.05)$ 


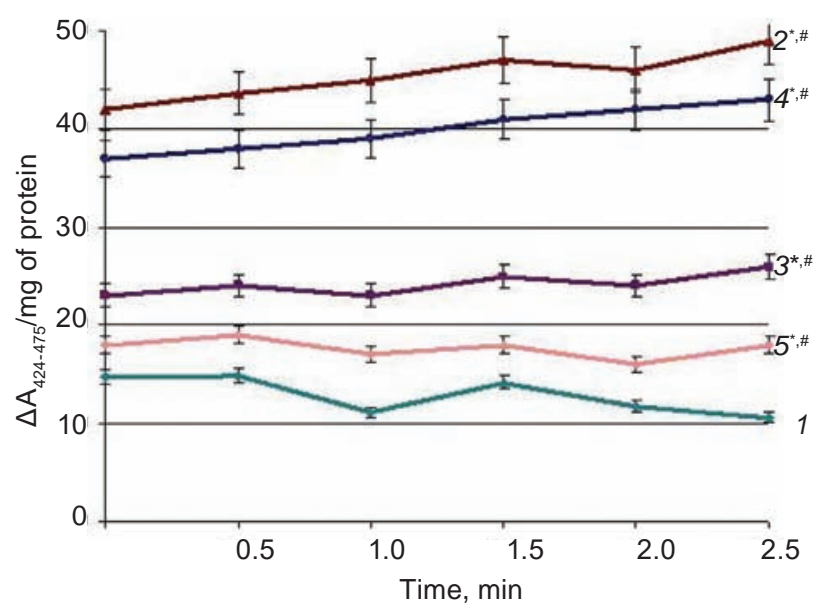

Fig. 6. The effects of $\omega-3$ polyunsaturated fatty acids and vitamin $D_{3}$ administration on the rate of cytochrome $b_{5}$ reduction in the liver microsomal fraction of tumor-bearing rats by the action of $\omega-3$ polyunsaturated fatty acids and vitamin $D_{3}: 1-$ intact animals; 2 - tumor-bearing rats in the period of intensive growth of the Guerin's carcinoma; 3 tumor-bearing rats that received $\omega-3$ PUFAs before and after transplantation of Guerin's carcinoma; 4 - tumor-bearing rats that were administered with vitamin $D_{3}$ before and after transplantation of Guerin's carcinoma; 5 - tumor-bearing rats that were administered with $\omega-3$ PUFA and vitamin $D_{3}$ before and after transplantation of Guerin carcino$\mathrm{ma}$; *statistically significant difference vs. control $(P \leq 0.05)$; ${ }^{\#}$ statistically significant difference vs. tumor-bearing rats $(P \leq 0.05)$

polyunsaturated fatty acids on the components of MOS can be achieved through changes in the expression of certain transcription factors, in particular PPAR (peroxisome proliferator-activated receptor). It has been recently shown that $\omega-3$ PUFAs activate PPAR $\alpha$. Such activation is capable of inducing the expression of enzymes involved in microsomal oxidation of fatty acids [22]. At the same time, $\omega-3$ PUFAs can influence CYP at the post-translational level directly interacting with the active center of the enzyme and stabilizing its molecule. For this reason, $\omega-3$ PUFAs are considered as effective alternative substrates in the pathways of CYP-dependent metabolism in liver cells [23].

In tumor-bearing rats, that received vitamin $\mathrm{D}_{3}$, there was no significant effect on the components of the reductase chain of MOS. Combined supplementation of $\omega-3$ PUFAs and vitamin $\mathrm{D}_{3}$ had no addi- tive effect as compared with the monotherapy of $\omega-3$ PUFAs.

The obtained results suggest that both $\omega-3$ PUFAs and vitamin $\mathrm{D}_{3}$, and especially their combination, exerted a pronounced correcting effect on the components of MOS oxygenase and reductase chains in the liver of tumor-bearing rats during the intensive growth of Guerin's carcinoma. The mechanism of such action of investigated lipophilic nutrients can be mediated by active (oxygenated) metabolites of $\omega-3$ PUFAs (EEQ, EDP, resolvin D1) and genomic effects of the hormonally active form of vitamin $\mathrm{D}_{3}-$ $1,25(\mathrm{OH})_{2} \mathrm{D}_{3}$.

\section{ЦИТОХРОМ Р450- ГІДРОКСИЛЮВАЛЬНА СИСТЕМА ПЕЧІНКИ ЩУРІВ- ПУХЛИНОНОСІЇВ ЗА ВВЕДЕННЯ Ф-3 ПОЛІНЕНАСИЧЕНИХ ЖИРНИХ КИСЛОТ ТА ВІТАМІНУ $\mathrm{D}_{3}$}

\author{
I. О. Шиманський', О. В. Кеца ${ }^{2}$, \\ М. М. Марченко ${ }^{2}$ М. М. Великий \\ ${ }^{1}$ Інститут біохімії ім. О. В. Палладіна \\ НАН України, Київ; \\ e-mail: ihorshym@gmail.com; \\ ${ }^{2}$ Чернівецький національний університет \\ імені Юрія Федьковича, Україна
}

У роботі досліджено вплив роздільної та сумісної дії омега-3 поліненасичених жирних кислот ( $\omega-3$ ПНЖК) і вітаміну $\mathrm{D}_{3}$ на активність компонентів оксигеназного та редуктазного ланцюгів монооксигеназної системи (МОC) мікросомної фракції печінки щурів із трансплантованою карциномою Герена. У печінці щурівпухлиноносіїв у період інтенсивного росту пухлини (14 діб, що відповідає логарифмічній фазі росту пухлини) послаблювалась функціональна активність оксигеназного ланцюга MOC: знижувалась активність $\mathrm{N}$-деметилази, n-гідроксилази та NADPH-цитохром P450-редуктази 3 одночасним зростанням швидкості інактивації цитохрому Р450 за рахунок його перетворення у неактивну форму - цитохром Р420. Натомість посилювалась функціональна активність редуктазного ланцюга МOC, компоненти якого передають електрони від відновленого NADH через $\mathrm{NADH}$-цитохром $b_{5}$-редуктазу та цитохром $b_{5}$ на цитохром Р450. Зокрема, зростала активність $\mathrm{NADH}$-цитохром $b_{5}$-редуктази та посилювалась 
швидкість відновлення цитохрому $b_{5} 3$ одночасним зменшенням його вмісту. $\omega-3$ ПНЖК та вітамін $\mathrm{D}_{3}$ за їх роздільного введення щурампухлиноносіям впродовж 42 діб (28 діб попереднього введення та 14 діб росту пухлини) значною мірою нормалізували оксигеназну активність MOC: відмічалося підвищення NADPHцитохром P450-редуктазної, $\mathrm{N}$-деметилазної, n-гідроксилазної активності цитохрому $\mathrm{P} 450$ та гальмування швидкості інактивації цитохрому Р450 в мікросомній фракції печінки. За поєднаного введення $\omega-3$ ПНЖК та вітаміну $\mathrm{D}_{3}$ мав місце їх синергізм. Зміни в активності компонентів редуктазного ланцюга МОC у печінці щурів-пухлиноносіїв спостерігались переважно за введення $\omega-3$ ПНЖК. Підвищувався вміст цитохрому $b_{5}$ та значно знижувалась швидкість його відновлення. За відсутності вираженої індивідуальної дії на редуктазний ланцюг МОС вітаміну $\mathrm{D}_{3}$ сумісне його введення 3 (-3 ПНЖК також не посилювало дію останніх.

К л ю чов і с лов а: $\quad \omega-3$ поліненасичені жирні кислоти, вітамін $\mathrm{D}_{3}$, цитохром $\mathrm{P} 450$, NADPH-цитохром Р450-редуктаза, цитохром $b_{5}$, $\mathrm{NADH}$-цитохром $\quad b_{5}$-редуктаза, мікросомна фракція, печінка.

\section{ЦИТОХРОМ Р450- \\ ГИДРОКСИЛИРУЮЩАЯ \\ СИСТЕМА ПЕЧЕНИ КРЫС- ОПУХОЛЕНОСИТЕЛЕЙ \\ ПРИ ВВЕДЕНИИ \\ ПОЛИНЕНАСЫЩЕННЫХ ЖИРНЫХ КИСЛОТ И ВИТАМИНА D $_{3}$}

\section{И. А. Шиманский \\ М. М. Марченко ${ }^{2}$ Н. Н. Великий}

\author{
${ }^{1}$ Институт биохимии им. А. В. Палладина \\ НАН Украины, Киев; \\ 凶e-mail: ihorshym@gmail.com; \\ ${ }^{2}$ Черновицкий национальный университет \\ имени Юрия Федьковича, Украина
}

В работе исследовано влияние раздельного и совместного действия омега-3 полиненасыщенных жирных кислот ( $\omega-3$ ПНЖК) и витамина $\mathrm{D}_{3}$ на активность компонентов оксигеназной и редуктазной цепей монооксигеназной системы (MOC) микросомной фракции печени крыс с трансплантированной карциномой Герена. В печени крыс-опухоленосителей в период ин- тенсивного роста опухоли (14 суток, что соответствует логарифмической фазе роста опухоли) ослаблялась функциональная активность оксигеназной цепи MOC: снижалась активность N-деметилазы, n-гидроксилазы и NADPHцитохром Р450-редуктазы с одновременным повышением скорости инактивации цитохрома P450 за счет его конверсии в неактивную форму цитохром Р420. Вместо этого усиливалась функциональная активность редуктазной цепи МОС, компоненты которой передают электроны от восстановленного NADH через NADH-цитохром $b_{5}$-редуктазу и цитохром $b_{5}$ на цитохром P450. B частности, повышалась активность NADHцитохром $b_{5}$-редуктазы и усиливалась скорость восстановления цитохрома $b_{5}$ с одновременным снижением его содержания. $\omega-3$ ПНЖК и витамин $\mathrm{D}_{3}$ при их раздельном введении крысамопухоленосителям в течение 42 суток (28 суток предварительного введения и 14 суток роста опухоли) в значительной мере нормализовали оксигеназную активность МОС: отмечалось повышение NADPH-цитохром P450-редуктазной, $\mathrm{N}$-деметилазной, n-гидроксилазной активности цитохрома $\mathrm{P} 450$ и торможение скорости инактивации цитохрома Р450 в микросомной фракции печени. При совместном введении $\omega-3$ ПНЖК и витамина $\mathrm{D}_{3}$ имел место их синергизм. Изменения активности компонентов редуктазной цепи МОС в печени крыс-опухоленосителей наблюдались преимущественно при введении $\omega-3$ ПНЖК. Кроме того, отмечено повышение содержания цитохрома $b_{5}$ и значительное снижение скорости его восстановления. При отсутствии выраженного индивидуального действия на редуктазную цепь МОС витамина $\mathrm{D}_{3}$ совместное его введение с $\omega-3$ ПНЖК также не было эффективным.

К лючевы е слов а: $\quad \omega-3$ полиненасыщенные жирные кислоты, витамин $\mathrm{D}_{3}$, цитохром P450, NADPH-цитохром Р450-редуктаза, цитохром $b_{5}$, NADH-цитохром $b_{5}$-редуктаза, микросомальная фракция, печень.

\section{References}

1. Sharma A, Hye Khan MA, Levick SP, Lee KS, Hammock BD, Imig JD. Novel Omega-3 Fatty Acid Epoxygenase Metabolite Reduces Kidney Fibrosis. Int J Mol Sci. 2016; 17(5). pii: E751.

2. Lee SM, Son YK, Kim SE, An WS. The effects of omega-3 fatty acid on vitamin $\mathrm{D}$ activation in 
hemodialysis patients: a pilot study. Mar Drugs. 2015; 13(2): 741-755.

3. Arnold C, Markovic M, Blossey K, Wallukat G, Fischer R, Dechend R, Konkel A, von Schacky C, Luft FC, Muller DN, Rothe M, Schunck WH. Arachidonic acid-metabolizing cytochrome P450 enzymes are targets of omega-3 fatty acids. J Biol Chem. 2010; 285(43): 32720-32733.

4. López-Vicario C, Alcaraz-Quiles J, GarcíaAlonso V, Rius B, Hwang SH, Titos E, Lopategi A, Hammock BD, Arroyo V, Clària J. Inhibition of soluble epoxide hydrolase modulates inflammation and autophagy in obese adipose tissue and liver: role for omega-3 epoxides. Proc Natl Acad Sci USA. 2015; 112(2): 536-541.

5. Moukayed M, Grant WB. Molecular link between vitamin $\mathrm{D}$ and cancer prevention. Nutrients. 2013; 5(10): 3993-4021.

6. Labudzynskyi DO, Shymanskyy IO, Riasnyi VM, Veliky MM. Vitamin $\mathrm{D}_{3}$ availability and functional activity of peripheral blood phagocytes in experimental type 1 diabetes. $U k r$ Biochem J. 2014; 86(2): 107-118. (In Ukrainian).

7. Tannour-Louet M, Lewis SK, Louet JF, Stewart J, Addai JB, Sahin A, Vangapandu HV, Lewis AL, Dittmar K, Pautler RG, Zhang L, Smith RG, Lamb DJ. Increased expression of CYP24A1 correlates with advanced stages of prostate cancer and can cause resistance to vitamin $\mathrm{D}_{3}$ based therapies. FASEB J. 2014; 28(1): 364-372.

8. Veliky MM, Apukhovska LI, Vasylevska VM, Lototska OJu, Bezusiak AI, Chomenko AV. Features of cholecalciferol hydroxylation process in the liver of rats under D-hypervitaminosis conditions and actions of $\alpha$-tocopherol. Ukr Biokhim Zhurn. 2010; 82(2): 67-74. (In Ukrainian).

9. Shmarakov IA, Katan NV. The Induction of Guerin's carcinoma cytochrome P450 hydroxylase activity by retinoids. Biochem (Moscow) Suppl Ser B: Biomedl Chem. 2011; 5(4): 369-375.

10. Schenkman JB, Cinti DL. Preparation of microsomes with calcium. Methods Enzymol. 1978; 52: 83-89.

11. Karuzina II, Archakov AI. Selection of the liver microsomal fraction and description of its oxidizing systems / Modern method in biochtmistry / Ed. VN Orechovich. M.: Meditsina, 1977. P. 49-62. (In Russian).
12. Mokhosoev IM, Kuznetsova GP, Al'terman MA, Bachmanova GI, Archakov AI. Inactivation of sodium dithionite reduced cytochromes P-450 of different origins. Biokhimiia. 1987; 52(10): 1649-1658. (In Russian).

13. Omura T, Sato R. The carbon monoxide-binding pigment of liver microsomes. II. Solubilization, purification, and properties. J Biol Chem. 1964; 239: 2379-2385.

14. Lowry OH, Rosebrough NJ, Farr AL, RandalL RJ. Protein measurement with the Folin phenol reagent. J Biol Chem. 1951; 193(1): 265-275.

15. Davidson J, Rotondo D, Rizzo MT, Leaver HA. Therapeutic implications of disorders of cell death signalling: membranes, micro-environment, and eicosanoid and docosanoid metabolism. $\mathrm{Br} \mathrm{J}$ Pharmacol. 2012; 166(4): 1193-1210.

16. Marchenko MM, Ketsa OV, Veliky NN. Biochemical transformation of xenobiotics in the body: monograph. Chernivtsi: Chernivtsi University, 2011. 280 p. (In Ukrainian).

17. Park JW, Reed JR, Brignac-Huber LM, Backes WL. Cytochrome P450 system proteins reside in different regions of the endoplasmic reticulum. Biochem J. 2014; 464(2): 241-249.

18. Ma Y, Trump DL, Johnson CS. Vitamin D in combination cancer treatment. J Cancer. 2010; 1: 101-107.

19. Shao Z, Fu Z, Stahl A, Joyal JS, Hatton C, Juan A, Hurst C, Evans L, Cui Z, Pei D, Gong Y, Xu D, Tian K, Bogardus H, Edin ML, Lih F, Sapieha P, Chen J, Panigrahy D, Hellstrom A, Zeldin DC, Smith LE. Cytochrome P450 2C8 w3-long-chain polyunsaturated fatty acid metabolites increase mouse retinal pathologic neovascularizationbrief report. Arterioscler Thromb Vasc Biol. 2014; 34(3): 581-586.

20. Maksymchuk OV. Influence of omega-3 polyunsaturated fatty acids on oxidative stress and cytochrome P450 2E1 expression in rat liver. Ukr Biochem J. 2014; 86(4): 132-137. (In Ukrainian).

21. Xiao X, Zhao W, Tian F, Zhou X, Zhang J, Huang T, Hou B, Du C, Wang S, Mo Y, Yu N, Zhou S, You J, Zhang Z, Huang G, Zeng X. Cytochrome b5 reductase 2 is a novel candidate tumor suppressor gene frequently inactivated by promoter hypermethylation in human nasopharyngeal carcinoma. Tumour Biol. 2014; 35(4): 3755-3763. 
22. Jump DB. N-3 polyunsaturated fatty acid regulation of hepatic gene transcription. Curr Opin Lipidol. 2008; 19(3): 242-247.

23. Arnold C, Konkel A, Fischer R, Schunck WH. Cytochrome P450-dependent metabolism of omega-6 and omega-3 long-chain polyunsaturated fatty acids. Pharmacol Rep. 2010; 62(3): 536-547.

Received 21.02.2018 